ENTREPRENEURSHIP AND SUSTAINABILITY ISSUES

ISSN 2345-0282 (online) http://jssidoi.org/jesi/

2019 Volume 7 Number 2 (December)

http://doi.org/10.9770/jesi.2019.7.2(16)

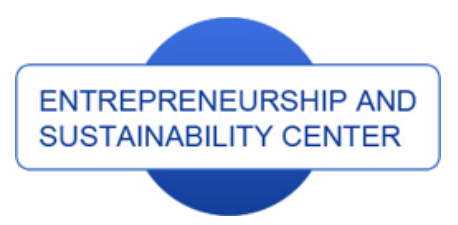

Publisher

http://jssidoi.org/esc/home

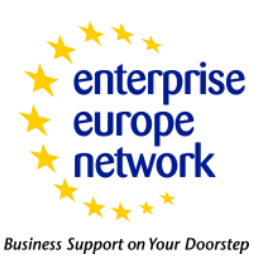

CASPA

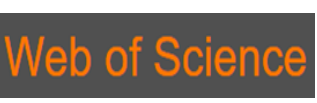

Clarivate
Analytics

\title{
MECHANISM OF AN IMPROVEMENT OF BUSINESS PROCESSES MANAGEMENT SYSTEM FOR FOOD PRODUCTION: CASE OF MEAT PRODUCTS ENTERPRISE*
}

\author{
Saule Ospandiyarovna Akhmetova ${ }^{1}$, Mariya Shayahmetovna Suleimenova ${ }^{2}$, \\ Maksim Borisovich Rebezov ${ }^{3}$ \\ 1,2 Almaty Technological University, Tole bi street 100, Almaty, 050012, Republic of Kazakhstan \\ ${ }^{3}$ K.G. Razumovsky Moscow State University of technologies and management (the First Cossack University), Zemlyanoy Val, \\ 73, Moscow, 109004, Russia \\ ${ }^{3}$ Ural State Agrarian University, Karl Liebknecht street 42, Yekaterinburg, 620075, Russia \\ ${ }^{3}$ V.M. Gorbatov Federal Research Center for Food Systems of the Russian Academy of Sciences, Talalikhin street, 26, \\ Moscow, 109316, Russia \\ E-mails: ${ }^{1}$ sunrise_kz@mail.ru; ${ }^{2}$ s.mariyash@mail.ru; ${ }^{3,4.5} \underline{\text { rebezov@ya.ru }}$
}

Received 15 March 2019; accepted 10 July 2019; published 15 December 2019

\begin{abstract}
On the basis of the conducted researches it is revealed that introduction of process approach at the studied enterprise is caused by a number of features without which creation of the process focused control system is impossible. From the most significant features are distinguished such, as a set of technological, production, operating and providing processes; high complexity of processes; production continuity; huge number of standard and technical documentation; duration of processes in time; specificity of the capital equipment. The analysis of the quality management system at the Becker \& K LLP enterprise is carried out; QMS business processes on IDEF0 methodology are developed. On the example of business process "To realize product release" actions for improvement of the mechanism of the business processes management system at the Becker \& K LLP are developed. Process of production and storage of products is considered and on its example the technique of assessment of the process approach effectiveness for the enterprise is offered. The process model of management, and also action for improvement of activity of the enterprise is developed.
\end{abstract}

Keywords: quality management system; process approach; business processes; decomposition; functional modeling; process inputs and outputs; meat cutting; meat boning; meat trimming; sausage stuffing; life cycle of production

Reference to this paper should be made as follows: Akhmetova, S.O., Suleimenova, M.S., Rebezov, M.B. 2019. Mechanism of an improvement of business processes management system for food production: case of meat products enterprise. Entrepreneurship and Sustainability Issues, 7(2), 1015-1035. http://doi.org/10.9770/jesi.2019.7.2(16)

JEL Classifications: L15, L23, L66, M11, Q01, Q13, Q18

Additional disciplines (besides field of economics reflected in JEL classifications): Chemical Engineering and Ecology.

\footnotetext{
* This research was supported by the project, which has received funding from the Ministry of Education and Science of the Republic of Kazakhstan, the Grant of a Scientific Project on the theme "Monitoring and optimization of food safety based on innovative nanotechnologies" (2015-2017, state registration number is 0115RK01777)
} 


\section{ENTREPRENEURSHIP AND SUSTAINABILITY ISSUES}

ISSN 2345-0282 (online) http://jssidoi.org/jesi/

2019 Volume 7 Number 2 (December)

http://doi.org/10.9770/jesi.2019.7.2(16)

\section{Introduction}

A serious competitive struggle caused development of quality improvement programs in the countries with the developed market economy. Worldwide, the relationship between large firms and their suppliers are long since based on quality management systems. For the consumer the quality system of the enterprise is a products quality assurance. The company's success in a market economy is based on high level of production organization, the core of which is a clear awareness and realization of each employee's responsibility and his role in achieving the company quality outcomes.

To the Quality Management System (QMS) corresponds the concept of general quality management since this system integrates organizational and functional structures of the quality management to operate business processes at each organizational level (Ponomarev S.V., Mironov S.V., 2007; Rodionova Yu.A., 2013). Application of the system significantly reduces the total number of required documents - various standards, orders, instructions, etc.

Business process (process) is a cumulative sequence of actions for transformation of the resources received at the input into the final product at the output that has a value to a customer (Standard of enterprise 7.2-02-2008; ST RK ISO 9001-2016; Repin V.V., Eliferov V.G., 2013).

Regarding to such a definition, it becomes clear that business processes exist at each organization, either formalized or not. Functional approach to management which considers the company as a set of divisions can be admitted to the organizations, each of which executes certain functions. In this case, each division is focused towards achieving its own goals rather than goals of the company, which, in some cases can negatively affect the general effectiveness of business (ST RK ISO 9001-2016; ST RK ISO 9004-2010; ST RK ISO 19011-2013; Gorshkov D.O., Kornilov D.A., 2015).

Technology of the description of business process does all operations of the company transparent and clear, allows to analyze operations and to find issues that cause failures. Existence of the developed system of business processes considerably simplifies matching company's activities with the requirements of ISO 9001 quality standards. Implementation of QMS at the enterprise without fail necessarily requires the creation and description of business processes.

This means that the issue of introducing the QMS and developing the business processes of the company QC is particularly relevant to date. The relevance of the topic is also defined by the fact that ensuring the competitiveness of any enterprise in the conditions of market economy is impossible without continuous improvement of its activity directed to improvement of quality of products. Quality assurance is a complex problem which has to be solved throughout the enterprise (Goldratt E.M., Cox J., 2009; Raver E.N., 2009; Shragenheim, E. 2014; Sobolkova A.V., 2008).

The purpose of this work was justification the feasibility of implementation process management at the selected enterprise and development recommendations and mechanism for optimizing core business processes as ways to improve the management system at the enterprise under study, as well as reviewing and developing business processes of the quality management system at the enterprise Becker \& K LLP. 


\section{ENTREPRENEURSHIP AND SUSTAINABILITY ISSUES}

ISSN 2345-0282 (online) http://jssidoi.org/jesi/

2019 Volume 7 Number 2 (December)

http://doi.org/10.9770/jesi.2019.7.2(16)

An object of the researches is activity of the enterprise in the form of the limited liability company "Becker \& $\mathrm{K}$ " in its interaction with other economic entities.

A subject of the research is the quality management system and the process of the enterprise quality management focused on improving competitiveness of the enterprise, as well as the main business processes of Becker \& K LLP.

As part of a systematic approach, methods of comparative, subject-object, functional-structural analysis and theoretical modeling were used in this paper. The theoretical and methodological background of the research became the concepts and hypotheses justified and presented in the modern scientific literature. The empirical base of the research are the analytical data published in scientific literature and periodicals, expert developments and assessments of Kazakhstan and foreign scientists, as well as materials on QMS of Becker \& K LLP.

\section{Literature review}

A number of researches of scientists from different countries have been devoted to issues of quality management and the development of business processes; considerable experience has been accumulated in the field of quality management. The scientific interest in the quality problem induces the analysis of accumulated theoretical material.

A great contribution to the development of currently used quality management systems was made by Russian scientists A.M. Dlin, V.S. Mkhitaryan, V.I. Siskov, as well as foreign scientists B.Bergman, L.Knowler, A.Feigenbaum. However, according to the authors, insufficient attention was paid to the problems of implementing quality systems at enterprises, and ways to adapt them.

A number of tools are used for modeling, analysis and evaluation of business processes, covering all stages of creating quality systems. The success of a project to create, maintain and develop a quality management system at the enterprise largely depends on the choice of certain tools. Graphical representation is the most acceptable way to describe the processes (Standard of enterprise 7.2-02-2008; Aksenova O. P., Aksenov K. A., Antonova S. A., Smoliy E. F., 2013).

Such integrated tools include the functional modeling methodology IDEF0, designed for enterprise design and management, modeling, documentation, analysis and evaluation of business processes, development and implementation of an information system.

The IDEF0 methodology is based on the approach developed by Douglas T. Ross in the early 70s and called SADT (structural analysis and design technology).

\subsection{Process approach. Processes classification}

"A process is a set of interconnected and interacting operations (actions) that transform inputs into outputs to add value" (Standard of enterprise 7.2-02-2008; ST RK ISO 9000:2016). The added value of the process is manifested in the increased effectiveness and efficiency of the organization as a result of deliberate changes in the process.

A business process is a set of processes and interactions between them, the result (output) of which is product and/or service delivered to consumers, while inputs are material, information and labor resources supplied by external suppliers. 


\section{ENTREPRENEURSHIP AND SUSTAINABILITY ISSUES}

ISSN 2345-0282 (online) http://jssidoi.org/jesi/

2019 Volume 7 Number 2 (December)

http://doi.org/10.9770/jesi.2019.7.2(16)

The main idea of the process approach can be reduced to the following theses (Kondrikov V.A., Plotnikov N.V., 2006; Bettina, Warzecha, 2017):

1) The activities of the organization must be presented in the form of a network of interacting processes;

2) Management of the organization activity should be based on managing a network of processes in order to increase their efficiency.

The structure of the management system, including quality management, built on the basis of the process approach, consists of two levels: management within each business process, as well as management of a group of business processes at the enterprise level.

Description of the network of processes of organization's activities is a complex organizational and technical task. Processes can be classified according to various criteria (Standard of enterprise 4.2.3.-05, 2005; Gorshkov D.O., Kornilov D.A., 2015):

Main (key) - processes, the immediate result of which is the release of products or the provision of services. Key processes have the greatest impact on achieving the organization's main goals;

Auxiliary (providing) - processes, the result of which is the creation of the necessary conditions for the implementation of the main processes;

Processes of management, the result of which is to increase the effectiveness and efficiency of the main and supporting processes;

Critical processes - represent an actual or potential danger to ensure product quality and, consequently, to business efficiency;

Management processes - processes which are owned by higher management (Raver E.N., 2009).

The implementation of process management is carried out in several stages.

- Process Inputs - input objects (raw materials, products, equipment, information or service) that are converted to Process Outputs during the execution of the Process. Often the inputs of one process are the outputs of another;

- Process Outcomes - products, information or services creation of which is the aim of the Process.

- The Network of Organization Processes - the integration of interconnected and mutually agreed Organization Processes into a single system (Gorshkov D.O., Kornilov D.A., 2015; Oschman, J.J. 2017).

Each process during decomposition can be divided into a number of subprocesses (business processes, works), the implementation of which leads to the creation of products with the specified parameters at the Process Output. Processes are chosen depending on the characteristics of a particular organization.

To improve the manageability of the Process, it is advisable to break it into a network of business processes. The number of business processes should also obey the $7 \pm 2$ law (the number of main processes) (Gorshkov D.O., Kornilov D.A., 2015). For the implementation of each business process, a responsible person from the department should also be appointed. An example of such a partition is shown in Fig. 1. 


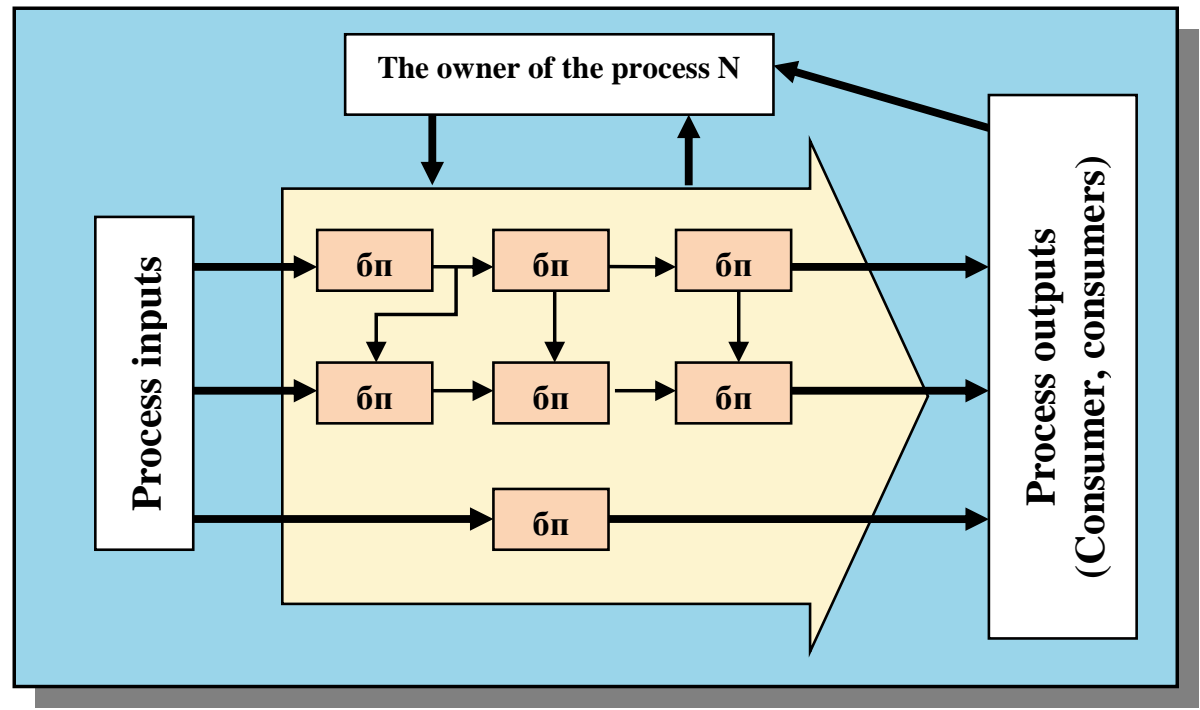

Figure 1. Decomposition of Process into the network of business processes

\subsection{Principles of business process modeling according to IDEF0 standard}

A number of tools are used for modeling, analysis and evaluation of business processes, covering all stages of management systems development. The most acceptable way to describe processes is graphical representation. Such integrated tools include the ARIS Toolset methodology, designed for enterprise design and management, modeling, documentation, analysis and evaluation of business processes, development, implementation of an information system (Bettina, Warzecha, 2017; Ogvozdin V.Yu., 2009). The ARIS Toolset toolkit contains over 80 models and methods for describing a business process. In the 70s, when implementing projects on the orders of the US Air Force, a program of integrated computer support for production (ICAM - Integrated Computer-Aided Manufacturing), and IDEF functional modeling methodology were developed. The methodology contains 11 standards from IDEF0 to IDEF11 (Shragenheim, E., 2014; Kuryan A.G., Serenkov P.S., 2001; P50.028-2001, 2000). The IDEF0 methodology is supported by computer programs. The use of computer programs at the stage of the process description allows not only to increase the efficiency of solving this problem, but also to use these models at the stage of process management, integrating them into the corporate information system of the organization. The functional model IDEF0 consists of two types of elements - functional blocks and arcs.

Each block in the framework of a single system under consideration must have its own identification number. Arcs connect functional blocks with each other and represent elements (objects) that are transmitted from the outputs of some processes to the inputs of others. Arcs, depending on their position in the diagram, are already divided into 4 categories: input, output, control and mechanism. These categories may include: Materials, raw materials, products, resources; Information, data; Quality records; Documents; Executive orders, plans, schedules; Normative documentation, standards; The matrix of responsibility of performers (P50.028-2001, 2000; Kuryan A.G., Serenkov P.S., 2001; Oschman, J.J. 2017). The third basic concept of the IDEF0 standard is Decomposition. The decomposition principle is applied when dividing a complex process into its constituent functions. The level of detail of the process is determined directly by the developer of the model. 


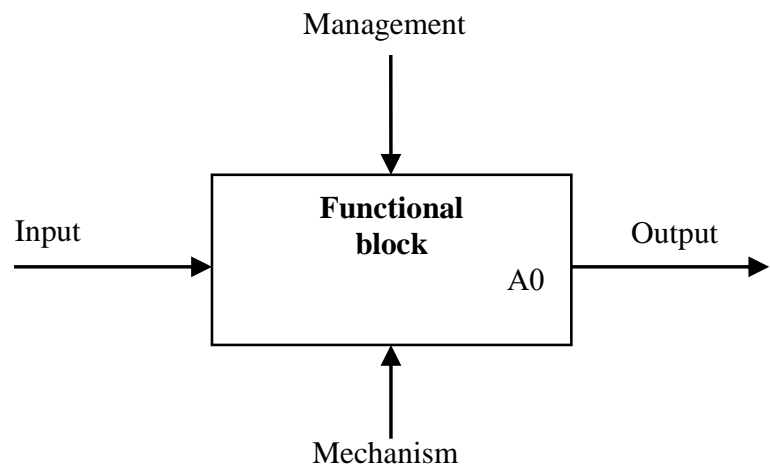

Figure 2. Functional block

Decomposition allows to gradually and structurally represent the system model in the form of a hierarchical structure of individual diagrams, which makes it easily digestible. The resulting second-level diagram contains the function blocks, that display the main subfunctions of the functional block of the context diagram and is called the subsidiary. In each case of decomposition of the functional block, all interface arcs included in this block or outgoing from it are fixed on the subsidiary diagram. This achieves the structural integrity of the IDEF0 model.

The last concept of IDEF0 is the Glossary. For each of the elements of IDEF0: diagrams, function blocks, arcs the standard implies the creation of a set of relevant definitions and keywords that characterize a given object (Matveev A. S., Rudenko A. Yu., Prochukhan V.V., 2016; Tsaprilov D.A., Chudaev A.V., 2007).

The process map. When describing processes, a process map should be drawn up. The process map is used to visualize and describe all the processes of the enterprise, and also establishes the relationship between the organizational structure and processes when creating added value. A process can be considered manageable if the impacts on it allow achieving goals and planned results (Matveev A.S., Rudenko A. Yu., Prochukhan V.V., 2016; Bardakov A.A., 2016).

\subsection{Assessment of business process indicators}

The basis of business process management is the measurement of its performance and effectiveness indicators; "Effectiveness - the degree of implementation of the planned work (activity) and the achievement of the planned results";

"Efficiency - the ratio between the achieved result and the resources used".

Three groups of indicators are often distinguished:

- costs of the business process, including the actual cost of the business process, calculated on the basis of the application of the ABC / CEA (Activity Based Costing / Cost-Effectiveness Analysis) methodology;

- temporal characteristics of the business process, cyclical nature, labor productivity;

- indicators of the quality of the business process (effectiveness).

When managing processes, vertical and horizontal "compression" of processes is possible (Ogvozdin V.Yu., 2009). Vertical "compression" is a reduction of the hierarchy of operations. Horizontal "compression" of processes - dividing a process into parallel branches, reduction of the time it takes to complete procedures. The 


\section{ENTREPRENEURSHIP AND SUSTAINABILITY ISSUES}

ISSN 2345-0282 (online) http://jssidoi.org/jesi/

2019 Volume 7 Number 2 (December)

http://doi.org/10.9770/jesi.2019.7.2(16)

combination of the process approach with managerial accounting, a team form of work organization and a project based lifestyle is the basis of a new organization, an organization of the 21 st century.

So, the need for the implementation of the QMS has "external" reasons for the company - access to the foreign market, competitive advantages among countries and firms.

However, "internal" reasons also have great importance: a greater awareness of quality; reduction of defects and costs of their removal; accelerating the production cycle and increasing labor productivity; positive cultural change, improved documentation management; increasing responsibility for the quality of their work; corporate culture, etc.

\section{Creation of business processes for QMS at the Becker \& K LLP enterprise}

\subsection{Analysis of the quality system effectiveness}

Becker \& K LLP is one of the first enterprises in Kazakhstan to introduce a quality management system in accordance with the requirements of the international standard ISO 9001. It is noteworthy that the quality management system was created here from the bottom up, not vice versa. This means that directly executing workers, heads of structural divisions developed procedures, process maps, instructions which are the basis of the mechanism of action of the management system.

Identification of environmental aspects and highlighting the most significant is an ongoing process that determines the past, present and potential impact of the Company's activities on the environment. All aspects of the Company in terms of environmental impact include two categories:

- direct (air emissions, wastewater, municipal solid waste);

- indirect (the effectiveness of the environmental management system, energy consumption, water use).

At the same time, the company integrated a food safety management system. This system allowed to concentrate the resources and efforts of the enterprise in critical areas of production, while sharply reducing the risk of producing and selling dangerous, non-conforming product standards. "Safety Planning" is an essential element in the formation of a security system, which allows ensuring food safety in the entire production and marketing chain. On this basis the process of achieving a high level of food product safety for the Company was modeled by consultants (Akhmetova S.O., Kulazhanova A.M., 2013; Quality manual of Becker \& K LLP, 2015; Annual reports of Becker \& K LLP, 2014-2018). It is presented in fig. 3.

The implemented food safety management system allows efficiently identify and eliminate potential risks and quickly respond to deviations from specified normative indicators exactly where they arise, without rebuilding the entire production process and reducing the total number of rejects, which means unjustified losses.

Thus, an integrated management system was gradually formed at the enterprise. The company launched such a system management that ensures strict adherence to the standards of ISO 9001, ISO 14001, ISO 22000, which does not allow for violations, and even more so, technological failures in operation, which allows us to guarantee the efficient operation of the Company as a whole. 
ENTREPRENEURSHIP AND SUSTAINABILITY ISSUES

ISSN 2345-0282 (online) http://jssidoi.org/jesi/

2019 Volume 7 Number 2 (December)

http://doi.org/10.9770/jesi.2019.7.2(16)

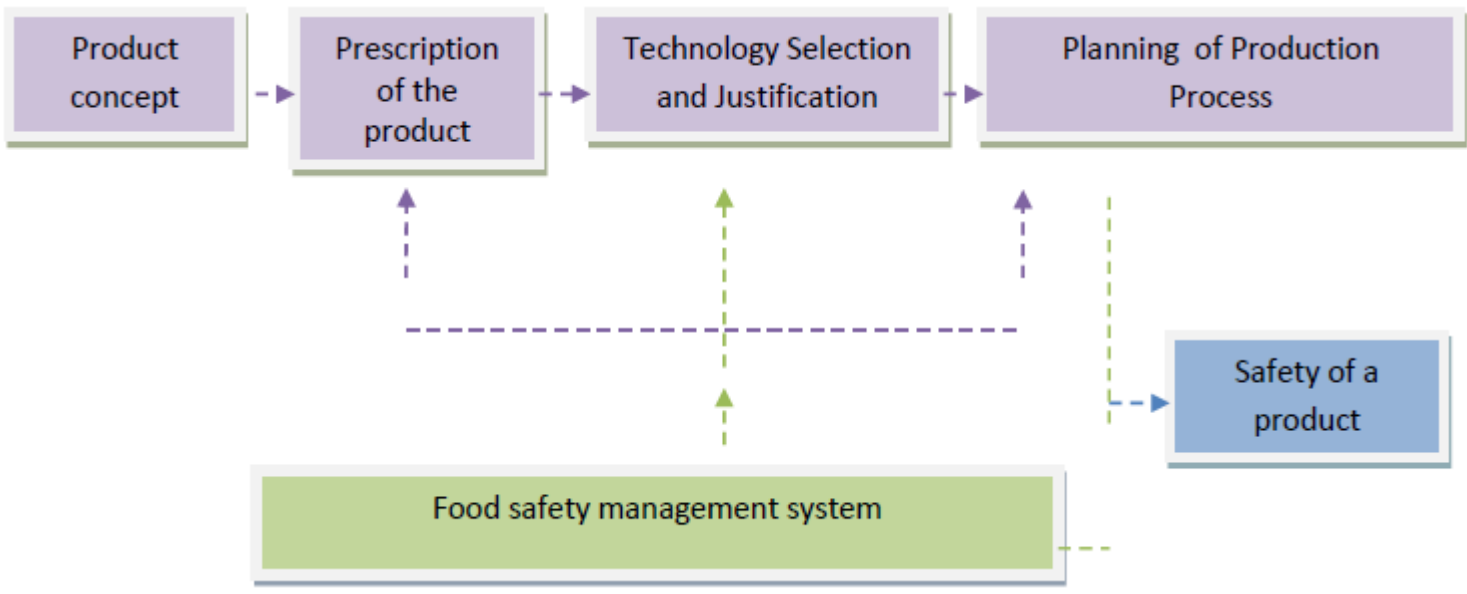

Figure 3. Model of the food product safety achievement process

Source: composed by the authors

Together, these three standards - ISO 9001, ISO 14001 and ISO 22000 - provide a powerful and complementary management system and make an equal contribution to the quality management, environment and food safety. The processes of the integrated management system, interacting with each other, preserve the integrity of the system when planning and implementing changes to it.

\subsection{The development of business processes of the product life cycle on the example of the "To realize the release of product" process}

A model of the organization's activity, an object of research engaged in the production of products, is proposed to facilitate understanding of the requirements of the ISO 9001 standard itself, as well as an example of constructing QMS. The model includes all standard processes, from design to service products. It represents a set of business processes of the organization with integrated requirements of ISO 9001:2015 (ST RK ISO 9000:2016; ST RK ISO 9001-2016; ST RK ISO 9004-2010 (IDT, ISO 9004-2009); ST RK ISO 10001-2009; ST RK 3.15.2-2009; ST RK 3.15.1-2009).

The IDEF0 functional modeling notation is used to describe the business process. The processes of the upper level of the model correspond to the key sections of the ISO 9001:2015 standard, then they are decomposed into subprocesses of the lower level directly in relation to the production and business activities of the organization.

One business process can be distinguished in the activity of the enterprise: "To realize the release of product". The inputs to this process are: a) external information, including the requirements of consumers (shops and companies); b) raw materials; c) resources. The outputs of the process are: a) finished products; b) information for external consumers (satisfaction). Process control is carried out on the basis of regulatory documents governing production processes in the enterprise. Considering that we are interested in the process from the point of view of quality management, we will consider regulatory documents regulating this area as external management. The decomposition of the business process at the enterprise is shown in Figure 4. Next, a map of the process is compiled (table 1).

Considering the goals of modeling - the compliance of the business process with the requirements of ISO 9001 the decomposition of the business process includes 4 process units shown in Figure 5.

In accordance with the requirements of ISO 9001, the "To realize the release of products" business process includes the following processes: 
- implement the responsibility of higher management on quality management;

- carry out resource management;

- implement life cycle processes;

- carry out measurements, analysis and improvement of QMS.

The interactions between the processes that make up the "To realize the release of products" business process is considered in figure 5 , table 2 .

The "To realize the responsibility of higher management on quality management" process is the governing process for all other processes. Accordingly, the output of this process - "Policy, goals, quality manual, quality programs" is the control input for all other processes shown in the diagram (Figure 5). The "To realize resource management" process has an "output - mechanism" connection with the "To realize life cycle processes" and "To perform measurements, analysis and improvement of the QMS" processes. The diagram shows the feedback loop: the output of the "To measure, analyze and improve the QMS" process with the input of the "To realize the responsibility of higher management on quality management" process.

The number of detalization levels of process is determined by the objectives of the simulation and the specifics of the activity of the simulated organization. In the framework of this methodology, the main goal of process modeling is to analyze the compliance of the process with the requirements of the quality management system.

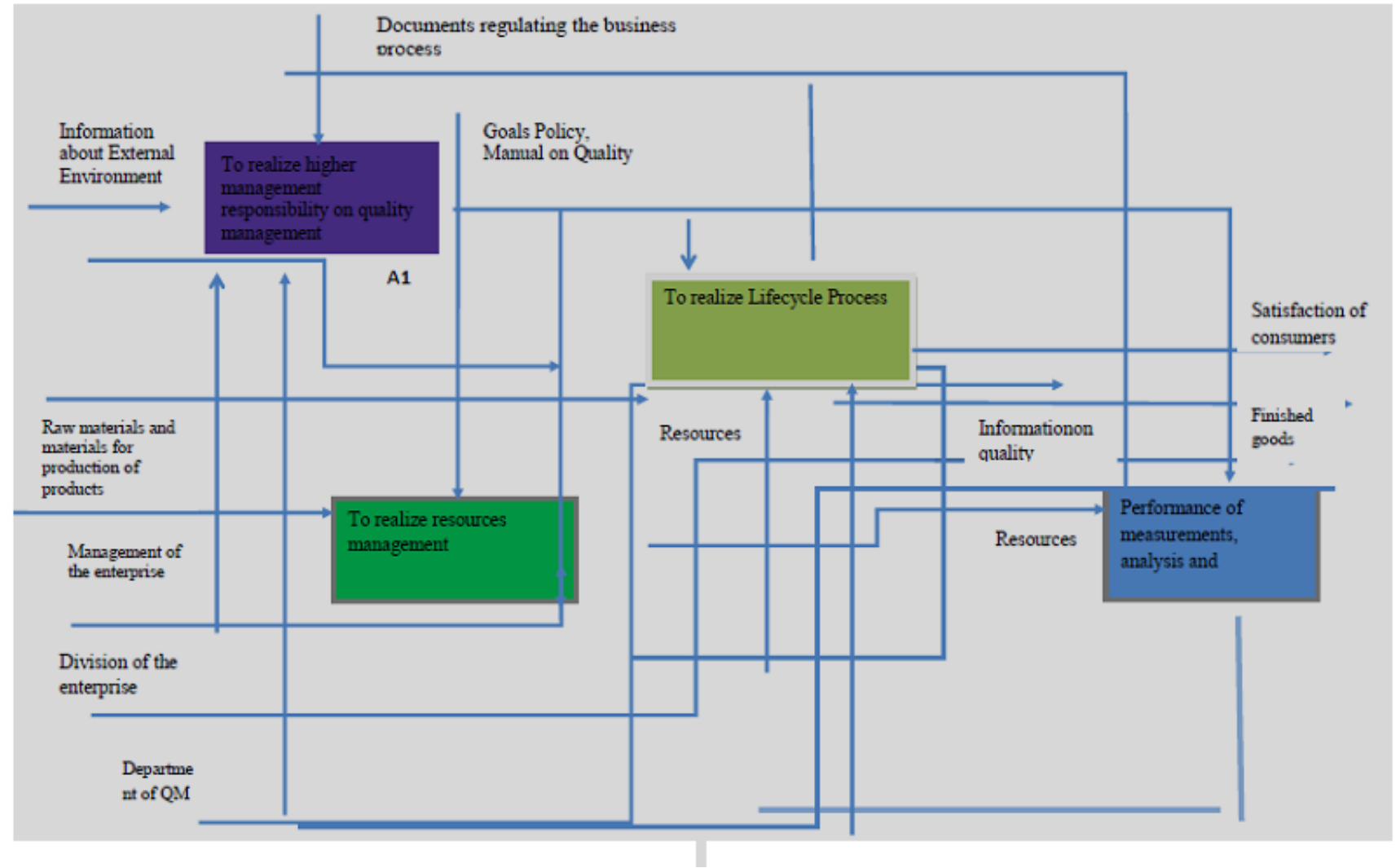

Figure 5. Decomposition of the process "Product release" Source: composed by the authors 
ENTREPRENEURSHIP AND SUSTAINABILITY ISSUES

ISSN 2345-0282 (online) http://jssidoi.org/jesi/

2019 Volume 7 Number 2 (December)

http://doi.org/10.9770/jesi.2019.7.2(16)

The "Product Release" business process at the diagram A0 is presented in the form of 4 processes. The diagram $\mathrm{A} 0$ is the first level of decomposition for this process. Each of the 4 presented processes, in turn, can be decomposed.

The authors have developed business processes of the quality management system.

The process cards required by the standard have been developed for all business processes.

Glossary - a set of relevant definitions, keywords that characterize a given business process. A common glossary has been developed for all diagrams.

The decomposition of work is terminated when the work of the lower level satisfies the following conditions:

1) The working process is clear and understandable to the manager and project participants (they are elementary);

2) The final result of each process and the overall work and the ways to achieve it are clear;

3) Timing characteristics and responsibility for the performance of work are uniquely defined.

\section{Assessment of functioning efficiency of Becker \& K LLP PROCESS MODEL ACTIVITY}

\subsection{Analysis of the production and storage of products process at Becker \& K LLP (on the example of the "Doctor's" cooked sausage production technology)}

Becker \& K LLP developed a process management model. This model provides four types of processes:

- system processes, which are divided into: document management, record management, non-compliance management, corrective and preventive actions, internal audit;

- management processes, which are divided into: strategic planning and improvement of IMS;

- business processes, which are divided into: analysis of consumer requirements, planning of production activities, technological preparation of production, production and storage, management of shipment of finished products, analysis of customer satisfaction;

- supporting processes, which are divided into: personnel management, information technology management, environmental management, equipment management; management of buildings and structures, construction management of new facilities, energy management, procurement, safety management, provision of vehicles.

As part of this section consider development of the process "Production and storage of product".

The first stage is the beginning the project performance. At this stage, internal and external initialization of the project is carried out.

The second stage is investigation. This stage includes a detailed view of the accounting areas and the specifics of the automated processes. At this stage, infological survey and survey of business processes, as well as their formalization, are carried out. Formalization of business processes includes the development of albums of functional diagrams, as well as diagrams of existing business processes in a customer's organization.

At the third stage, the system is designed. Design models of implemented subsystems are created, as well as prototypes of objects of the developed information system.

At the fourth stage, the technical specification is compiled. Also at this step an assessment of the complexity of solving the problem for all objects of the technical specification is carried out. At this stage, programming, testing, development of test cases and user documentation for the information system is carried out. 
The fifth stage includes training and consulting users of the system. After that, the information system is put into use at the enterprise and its operation by users begins.

At the final stage, the results are formalized and the project is actually completed. The results of the project are summarized and project resources are released (Repin V.V., Eliferov V.G., 2013).

Let us present a description of the "Production and storage of product" process using the example of the production of cooked sausage "Doctor's" at Becker \& K LLP.

3.2 Development of the "Production and storage of product" process on the example of cooked sausage production technology at Becker \& K LLP

The process includes the following activities: ensuring the production of products of a given assortment that meets the requirements of standards and the requirements of the consumer for quality, in volumes established by production plans. Organization of operational production management (scheduling) is presented in Fig. 6.

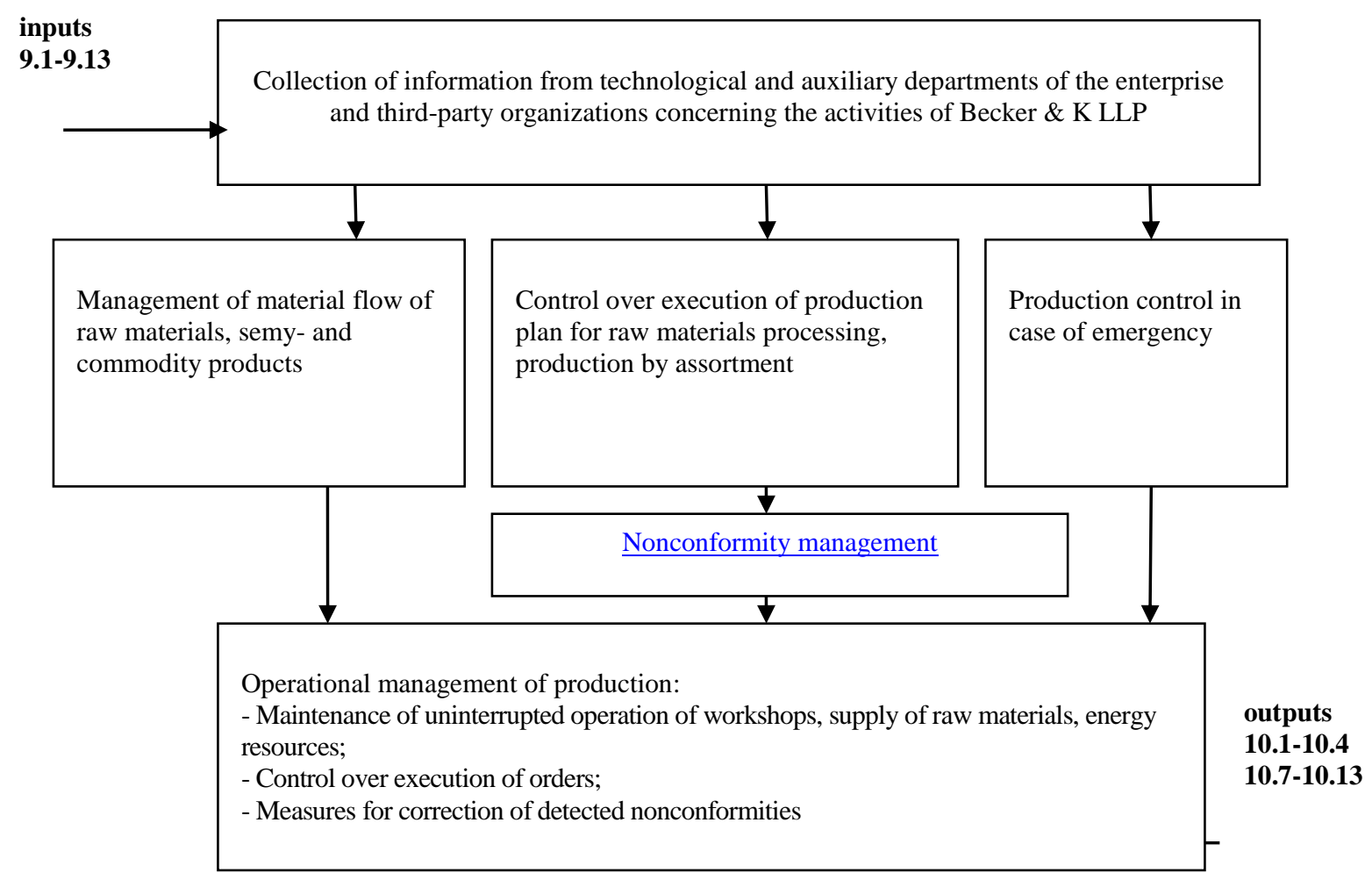

Figure 6. Organization of operational management of production Source: composed by the authors

Then it turns into the process of intake, account, storage of meat raw materials. Schematically the process can be presented in a form of figure 7. 


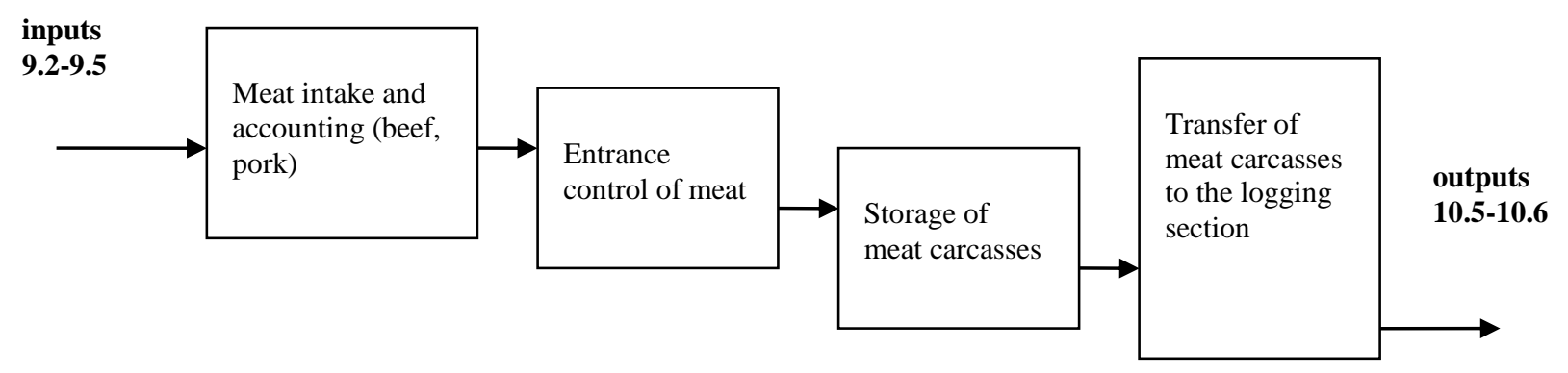

Figure 7. Scheme of intake, account, storage of a raw meat Source: composed by the authors

The next stage is the primary processing of meat and the production of marketable meat products. This stage can be distinguished as the main process of a meat processing plant, since it starts the processing of raw materials and turning it into finished products. Marketable meat products and the marketable product (cooked sausage) production process is presented in the form of a diagram in Figure 8 (Rogov I.A., Zabashta A.G., Kazyulin G.P., 2000; Rogov I.A., Zabashta A.G., Kazyulin G.P., 2009).

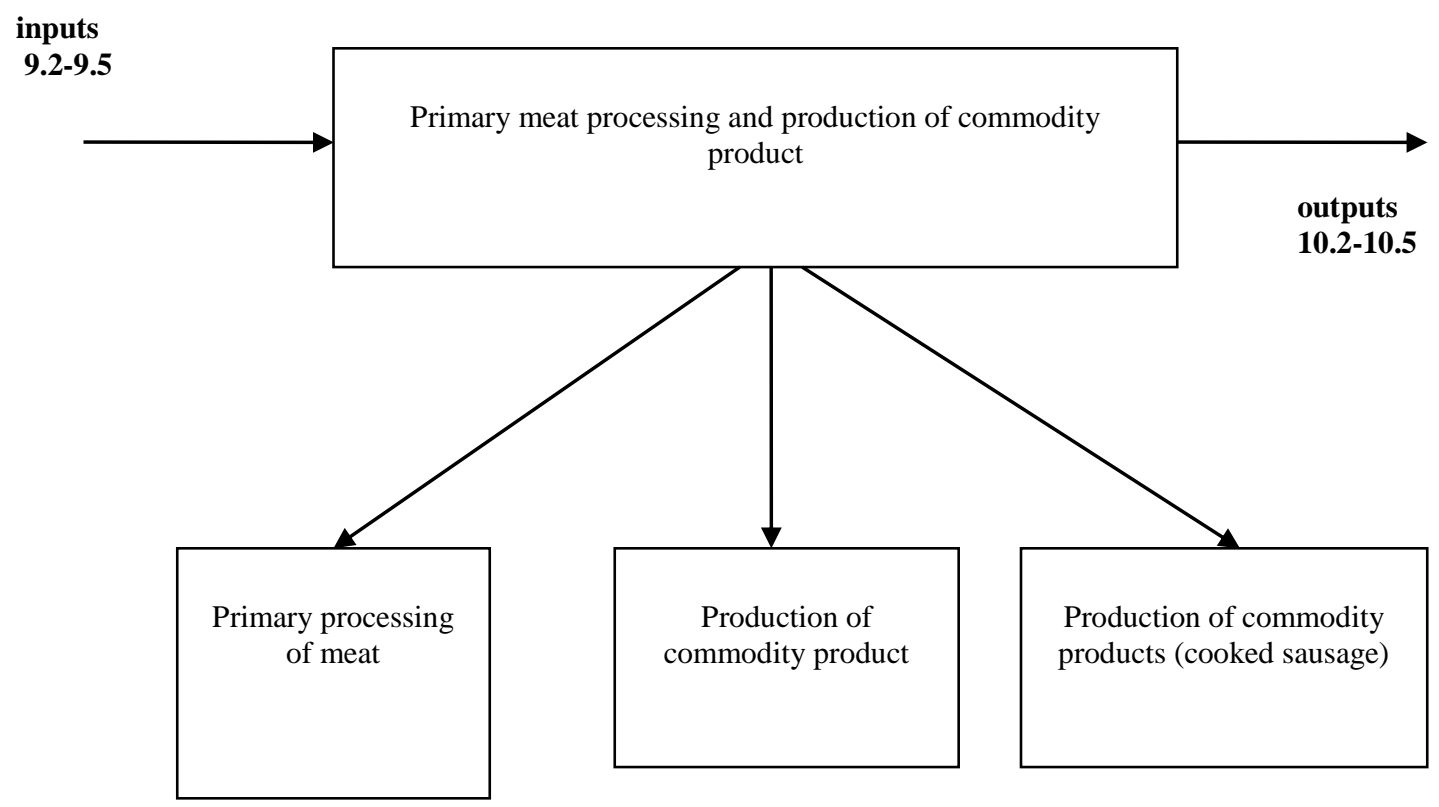

Figure 8. Primary processing of meat and production of marketable products Source: composed by the authors

Processing of raw materials and production of meat products with a view to their further realization in the domestic and foreign markets is presented in Figure 9. 


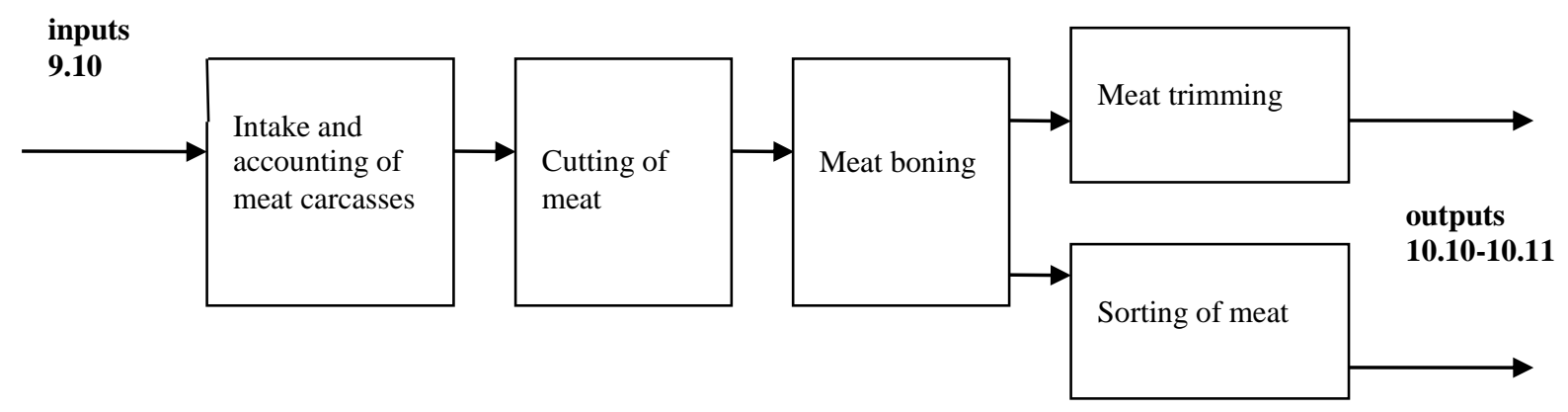

Figure 9. Primary processing of meat carcasses Source: composed by the authors

Chopping, salting and ripening of meat, as well as the preparation of minced meat are presented in Figure 10.

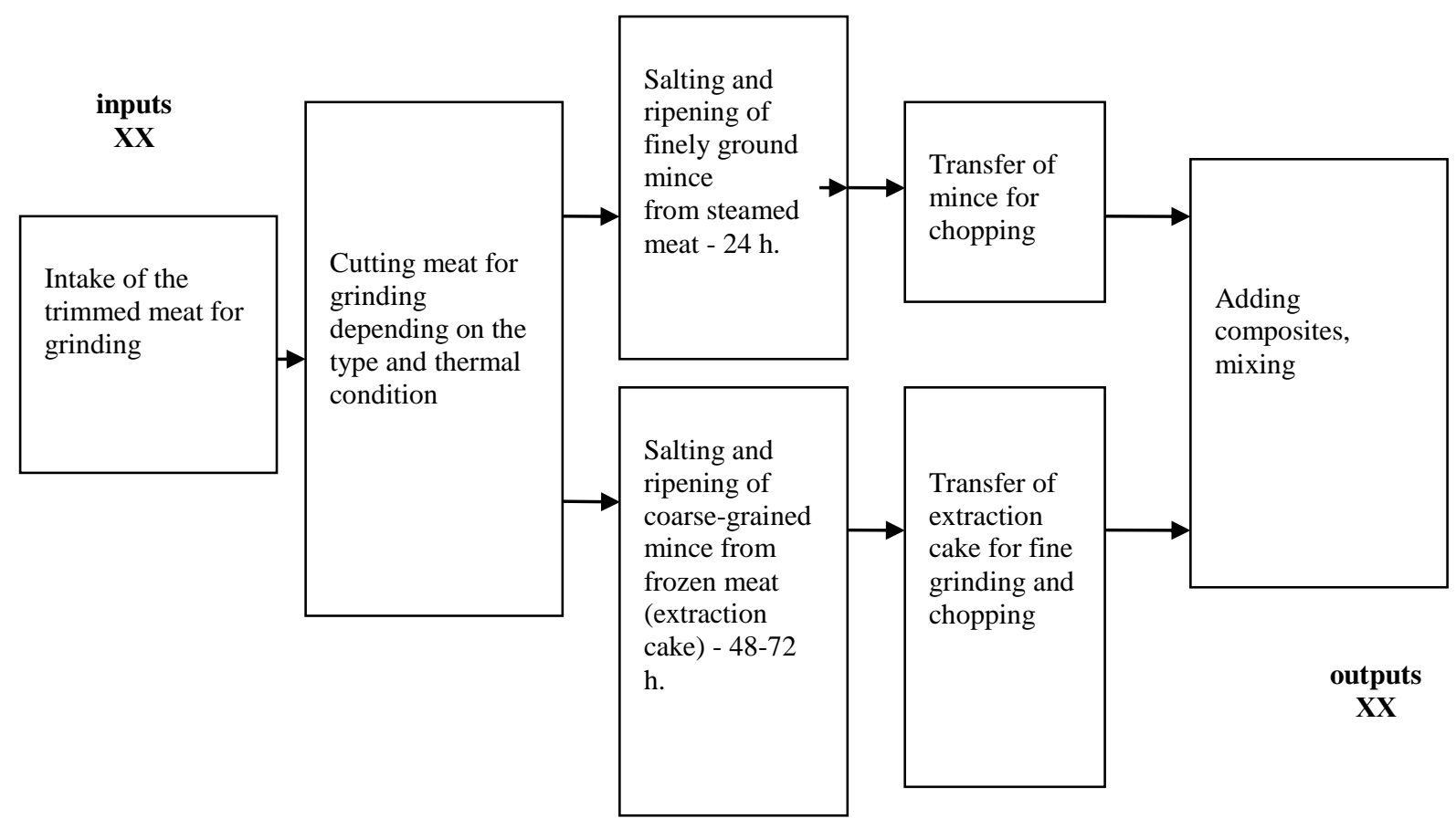

Figure 10. Preparation of minced meat Source: composed by the authors 


\section{ENTREPRENEURSHIP AND SUSTAINABILITY ISSUES}

ISSN 2345-0282 (online) http://jssidoi.org/jesi/

2019 Volume 7 Number 2 (December)

http://doi.org/10.9770/jesi.2019.7.2(16)

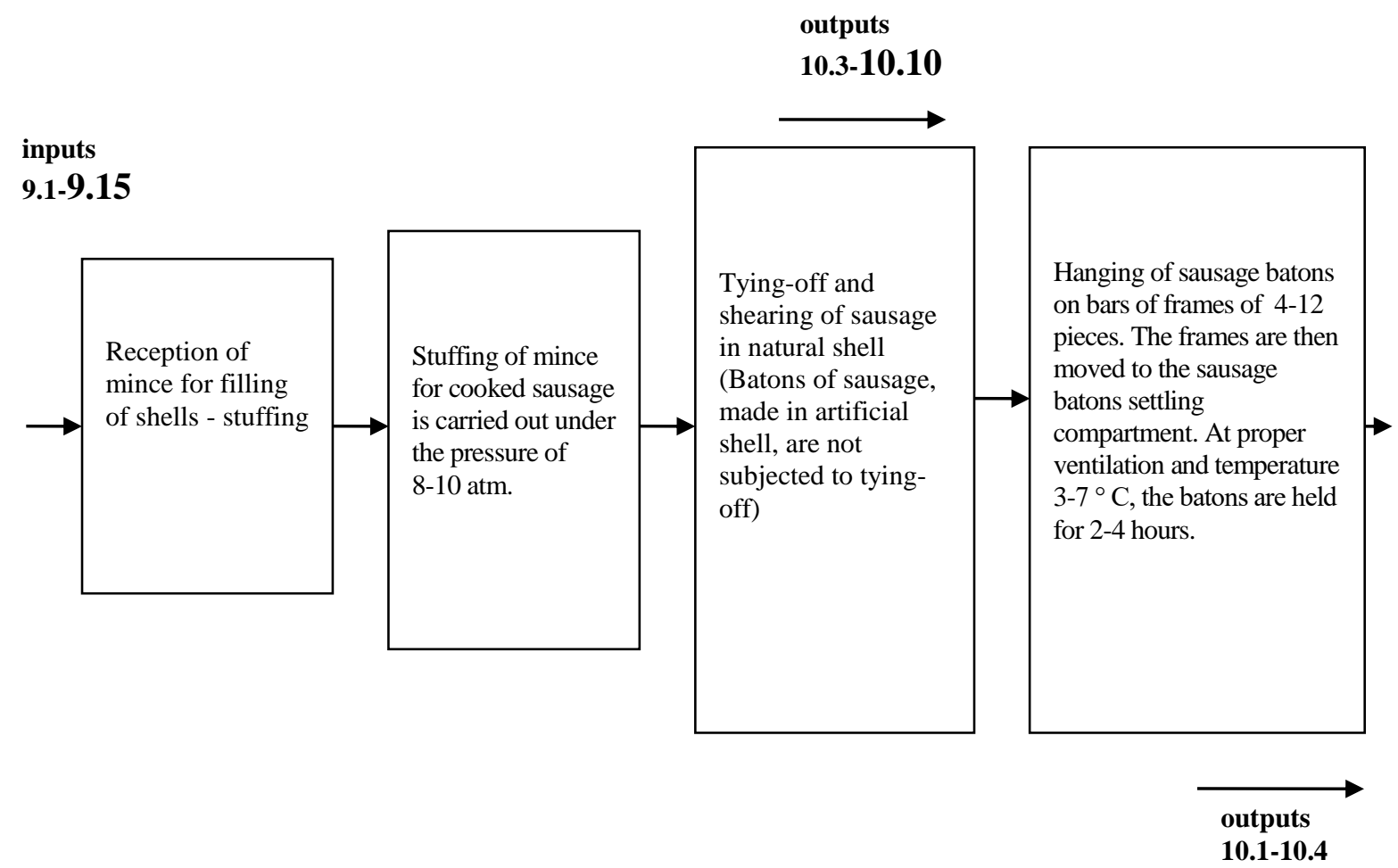

Figure 11. Stuffing, tying-off and sedimentation Source: composed by the authors

After that the process of heat treatment (cooked sausages) and cooling, storage and shipment of marketable products are carried out (Figure 12). 
inputs

9.13-9.19

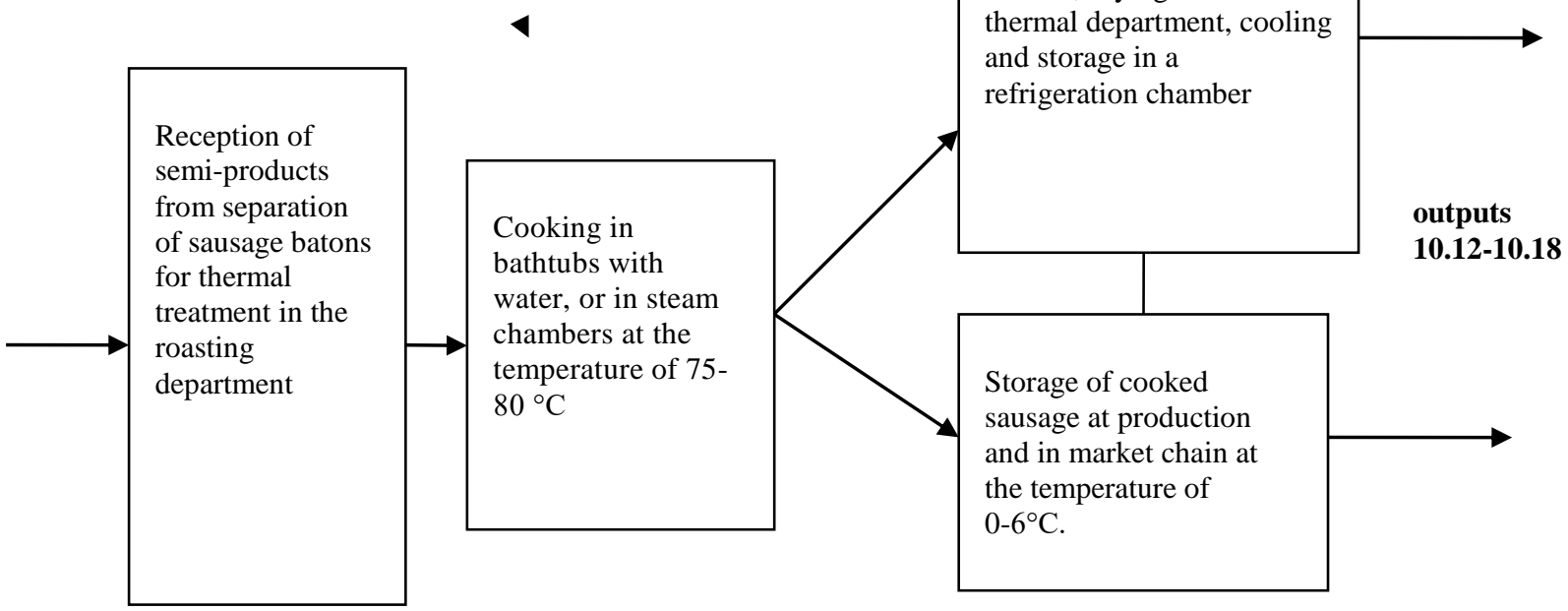

Figure 12. Receiving of marketable meat products, storage and shipment Source: composed by the authors

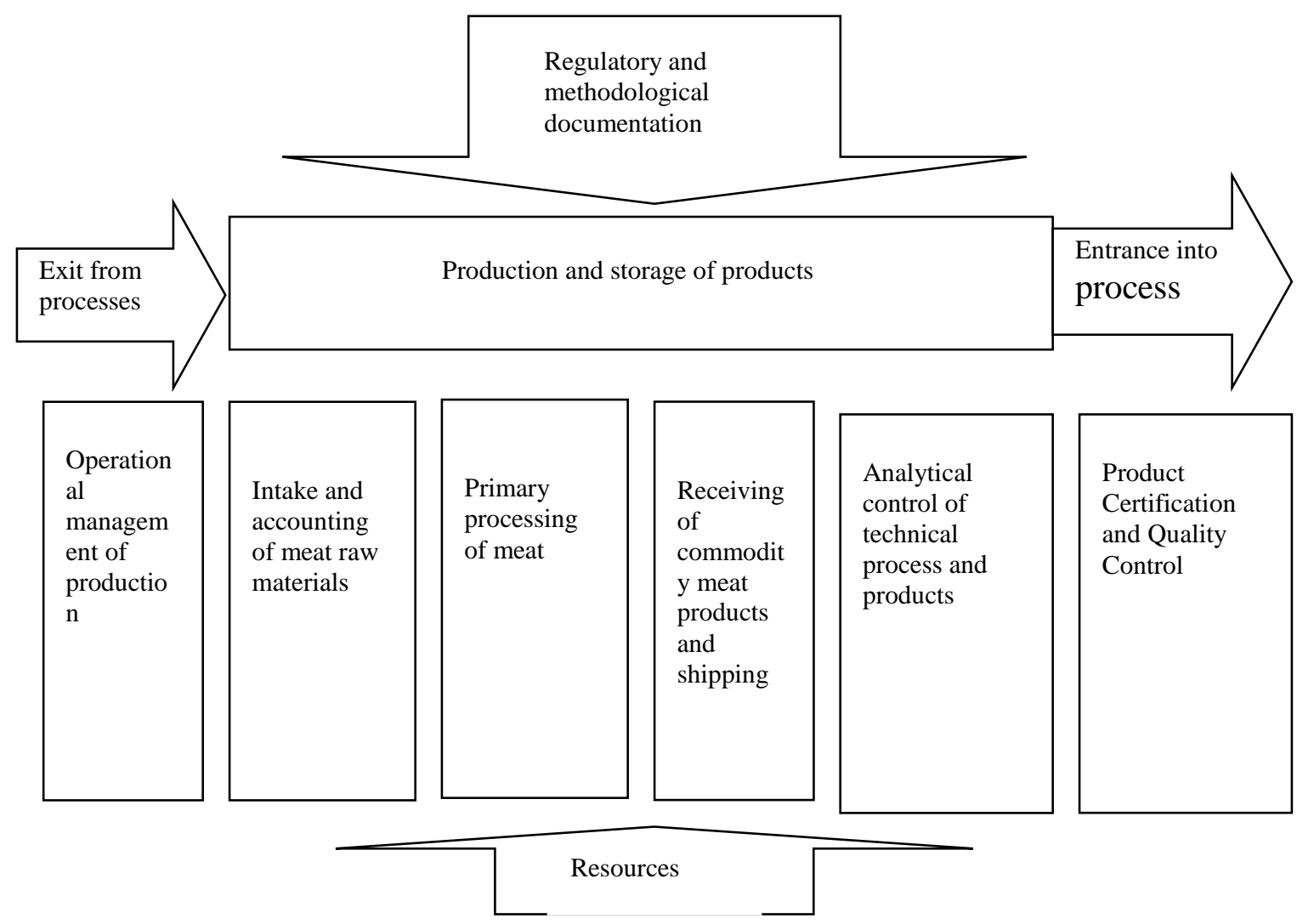

Figure 13. Process of the top level Source: composed by the authors 


\section{ENTREPRENEURSHIP AND SUSTAINABILITY ISSUES}

ISSN 2345-0282 (online) http://jssidoi.org/jesi/

2019 Volume 7 Number 2 (December)

http://doi.org/10.9770/jesi.2019.7.2(16)

The process ends with analytical (operational) control of the technological process and products.

Risks of the process of production and storage of products:

- non-fulfillment of the production plan, financial losses;

- claims and complaints of consumers;

- low profitability of production, loss of market;

- loss of the image of the enterprise .

In general, the "Production and storage of products" process is represented in figure 13.

Thus, the process of production and storage of products is the interconnection of the following activities: ensuring the production of products of a given assortment that meets the requirements of standards and the requirements of the consumer for quality, in volumes established by production plans. Based on the foregoing, it is necessary to analyze the effectiveness and efficiency of the production process and storage in order to reduce and prevent the risks stated above.

\subsection{Assessment of the effectiveness of the process based approach in the activities of Becker \& K LLP}

Assessment of effectiveness involves two components: evaluation of the effectiveness of the quality management system and evaluation of the effectiveness of the processes of this system. Of particular importance for assessment the effectiveness of processes is the availability of criteria, ranked by degree of importance for the process. The importance of the criteria is determined by the consumer of the process results.

For assessment of QMS processes effectiveness the technique "The analysis of criteria for evaluation of processes of a quality management system" was used (Kuryan A.G., Serenkov P.S., 2001). The main goal of development of this technique is the description of the assessment procedure of criteria of process based on their ranging on importance degree for the analysis of effectiveness of process.

In the framework of this work, a technique for developing the effectiveness of the "Production and storage of products" process was considered (Tsaprilov D.A., Chudaev A.V., 2007). The developed technique provides the gradation of criteria, which takes into account the importance of each criterion for a particular process:

1) Needed;

2) Unimportant;

3) Medium importance;

4) Very important;

5) Maximum importance.

When determining the rating scale, the range into which a particular criterion should fall is determined, the maximum number of points is assigned to the best criterion value. In order to avoid cases of incorrect assessment of the effectiveness of the process according to existing criteria, a "generalized indicator" is proposed, i.e. if there are two or more criteria of the same type in the process (effectiveness, efficiency, etc.), it is necessary to use a generalized indicator for decision-making in the analysis of the process. A complex (integrated) indicator can be considered as a synonym for a generalized indicator. To calculate the generalized indicator, it is necessary to calculate all the process criteria for a certain period (Matveev A.S., Rudenko A.Yu., Prochukhan V.V., 2016; Bojkovska K., Tomovska J., Shariati M. A. 2014; Detmer W., 2012).

In the developed technique, interpretation options for the results of the obtained value of the generalized indicator are provided, further the range may change, which can be seen in table 2 . 


\section{ENTREPRENEURSHIP AND SUSTAINABILITY ISSUES}

ISSN 2345-0282 (online) http://jssidoi.org/jesi/ 2019 Volume 7 Number 2 (December) http://doi.org/10.9770/jesi.2019.7.2(16)

Table 2. Generalized indicator of effectiveness (Source: composed by the authors)

\begin{tabular}{|c|c|}
\hline $97-100 \%$ & The process is productive. \\
\hline $80-97 \%$ & The process is productive, but needs improvement. \\
\hline $70-79 \%$ & The process is conditionally effective, requires corrective action \\
\hline less than $70 \%$ & The process is ineffective. \\
\hline
\end{tabular}

This calculation of the generalized indicator is carried out with the frequency indicated in the specification for the process. In order to assess the effectiveness of the QMS as a whole, as well as ensuring continued suitability, adequacy of the system, the "Assessing the suitability, adequacy and effectiveness of the QMS" technique was developed. This technique establishes a procedure for evaluating the QMS of a factory. The suitability of the QMS is determined on the basis of customer satisfaction, as well as the achievement of quality goals. QMS is considered suitable when receiving more than $80 \%$ of positive responses.

The adequacy of the QMS is the conformity of the requirements of the QMS to the requirements of international standards and the requirements of consumers. The adequacy of the QMS is determined based on the results of audits. QMS is considered adequate when receiving more than $80 \%$ of positive responses.

The effectiveness of QMS is one of the most important stages of its functioning, in which the enterprise is able to manage interconnected processes as a system. The effectiveness of QMS is determined on the basis of data on the course of processes and the conformity of products, the status of corrective and preventive actions, as well as actions taken based on the results of previous analyzes by the management. Table 3 presents the effectiveness of the quality management system (Kuryan A.G., Serenkov P.S., 2001; Bardakov A.A., Kornilov D.A., 2017).

Table 3. The effectiveness of QMS

\begin{tabular}{|c|c|c|c|}
\hline \multirow[t]{2}{*}{ Information } & \multirow{2}{*}{$\begin{array}{l}\text { Information content (evaluation } \\
\text { criteria) }\end{array}$} & Score & \multirow[t]{2}{*}{ Remarks } \\
\hline & & Yes/1 No/0 & \\
\hline \multirow[t]{6}{*}{ QMS Processing Data } & \multirow{6}{*}{$\begin{array}{c}\text { Is the process productive? (data } \\
\text { on top-level processes are } \\
\text { considered) }\end{array}$} & 1 & "Provision of qualified personnel" - effective. \\
\hline & & 1 & "Quality Management" - effective. \\
\hline & & 1 & "Production and shipment of products" - effective. \\
\hline & & 1 & "Technological support" - effective. \\
\hline & & 1 & "Purchases of raw materials and materials" - effective. \\
\hline & & 1 & "Provision of workable equipment" - effective \\
\hline $\begin{array}{l}\text { Product Compliance } \\
\text { Data }\end{array}$ & $\begin{array}{l}\text { Does the level of product } \\
\text { quality meet the plan? }\end{array}$ & & \\
\hline \multirow{2}{*}{$\begin{array}{l}\text { The degree to which } \\
\text { decisions of previous } \\
\text { analyzes are } \\
\text { implemented by } \\
\text { management }\end{array}$} & $\begin{array}{c}\text { Are the solutions of the } \\
\text { previous analysis implemented? }\end{array}$ & 1 & All decisions of the previous analysis are implemented. \\
\hline & Are the deadlines met? & 1 & Deadlines are met \\
\hline
\end{tabular}

All the features of the application of the process approach in industry were taken into account while developing the techniques. It results in the possibility of drawing real conclusions about the effectiveness of the developed model of the QMS process after the start-up of the plant and the start of production. Criteria for evaluating the effectiveness of the "Production and storage of products" process will be found. The application of this technique allows the company to conduct a periodic QMS assessment and guarantee to consumers that all their requirements and expectations regarding the quality of finished products, and production technologies and control methods are fully implemented (Dentovskaya Yu.S., 2016; Ishimova A.Yu., Gareeva G.A., 2015). 


\section{ENTREPRENEURSHIP AND SUSTAINABILITY ISSUES}

ISSN 2345-0282 (online) http://jssidoi.org/jesi/

2019 Volume 7 Number 2 (December)

http://doi.org/10.9770/jesi.2019.7.2(16)

\section{Conclusions}

Implementation of process approach at the industrial enterprise is caused by a number of features. The most significant features are: a large number of processes, complexity of their performance and assessment of effectiveness, big number of staff, huge number of standard and technical documentation, wide nomenclature of the purchased raw materials and materials, specificity of the capital equipment.

At the same time implementation of process approach promotes steady and productive functioning of the industrial enterprise in market conditions of managing. Realization of process approach assumes use of various tools: description of the scheme of a stream of processes, modernization of processes, description of their inputs and outputs, effectiveness assessment.

As a result of the done work the following tasks were solved:

- Theoretical and methodological basics of quality management and development of business processes of the enterprise are covered;

- The analysis of the quality management system at the Becker \& K LLP enterprise is carried out and business processes of QMS on IDEF0 methodology are developed;

- On the example of business process "To realize product release" actions for improvement of the mechanism of the business processes management system at the Becker \& K LLP enterprise are developed;

- The process model of management, and also action for improvement of activity of the enterprise is developed. The analysis of development of the enterprise activity process model on the example of Becker \& K LLP is carried out. Process of production and storage of products is considered and also the technique of assessment of effectiveness of process approach for the enterprise is offered;

- the business management subsystems including target, functional and organizational subsystems and a subsystem of interaction with the external environment are systematized and their interaction with a quality management subsystem is defined.

The estimated practical implication is that its recommendations have purposeful character in the conditions of market economy and allow increasing effective quality management at the enterprise. Implementation of offers on introduction and improvement of process approach at management of the industrial enterprise allows using rationally resources of the enterprise for ensuring the level of quality of products meeting requirements of consumers.

\section{References}

Akhmetova, S.O., Kulazhanova, A.M. (2013). The mechanism of improvement of the management system of Akhmetova S.O., Kulazhanova A.M. (2013). The mechanism of improvement of the management system of business processes at the Becker \& K LLP enterprise. Journal of ATU, Almaty, 1, 33-41. elibrary.ru/contents.asp?issueid=1358039

Aksenova, O.P., Aksenov, K.A., Antonova, S.A., Smoliy, E.F. (2013). Analysis of graphical notations for simulation modeling of business processes of the enterprise. Modern Problems of Science and Education, 4.

Bardakov, A.A. (2016). The formation of modern reengineering of business processes of industrial enterprises, the transition from a functional type of management to process. IT Portal, 3(11). URL: http://itportal.ru/science/economy/stanovlenie-sovremennogo$\underline{\text { reinzhinir/ }}$ 


\section{ENTREPRENEURSHIP AND SUSTAINABILITY ISSUES}

ISSN 2345-0282 (online) http://jssidoi.org/jesi/

2019 Volume 7 Number 2 (December)

http://doi.org/10.9770/jesi.2019.7.2(16)

Bardakov, A.A., Kornilov, D.A. (2017). Application of the theory of limitation of Goldratt systems in the framework of business process reengineering in production planning for an industrial enterprise. Иннов: электронный научный журнал, 4(33) http://www.innov.ru/science/economy/primenenie-teorii-ogranicheniya-sis/

Bettina, Warzecha. (2017). Problem with Quality Management Process orientation, controllability and zero-defect processes as modern myths. Walsrode.

Bojkovska, K., Tomovska, J., Shariati, M.A. (2014). Conteporary Quality Management System Elements in the Food Industry. VestnikOrelGAU, 6(51), 48-50.

Dentovskaya, Yu.S. (2016). Reengineering of business processes. Bulletin of Science and Education, 2(14), 39-48.

Detmer, W. (2012). The theory of Goldratt's limitations: A systematic approach to continuous improvement. Moscow: Alpina Pablisher, $443 \mathrm{p}$.

Goldratt, E.M., Cox, J. (2009). The process of continuous improvement. Minsk: Potpourri, 496 p.

Gorshkov D.O., Kornilov D.A. (2015). Evaluation of the effectiveness of business processes in the framework of multi-level strategic planning of diversified companies. Economic analysis: Theory and Practice, 44(443), 2-14.

Ishimova A.Yu., Gareeva G.A. (2015). Analysis and reengineering of business processes of the enterprise, Science Time 2(14), 57-61.

Kondrikov V.A., Plotnikov N.V. (2006). Effectiveness and efficiency of QMS of the enterprise, Quality Management Methods No. 10, p. 27-31. https://cyberleninka.ru/

Kuryan A.G., Serenkov P.S. (2001). Implementation of the process approach within quality management systems based on the methodology of IDEF0 functional modeling, www.orientsoft.by

Kuryan A.G., Serenkov P.S. (2001). Use of IDEF0 to describe and classify processes within the quality system of ISO MS 9000 Series 2000. - Minsk.

Manual reports of Becker \& K LLP (2014-2018).

Materials from the official website of Becker \& K LLP http://www.becker.kz

Matveev A.S., Rudenko A.Yu., Prochukhan V.V. (2016). Development of recommendations for transition from IDEF0 notation of business processes modeling to BPMN notation. Business. Education. Law. Bulletin of Volgograd Business Institute, 3(36), 176-182.

Maximova N.V. (2009). Improvement of food enterprise's quality management systems on the basis of analysis and improvement, Food Industry, 4, 56-61. www.dissercat.com

Ogvozdin V.Yu. (2009). Quality management. Basics of Theory and Practice: Tutorial. - Moscow: Publishing House "Case and Service," $160 \mathrm{p}$.

Oschman, J.J. (2017). The Role of Strategic Planning in Implementing a Total Quality Management Framework: An Empirical View, Quality Management Journal, 24(2) https://doi.org/10.1080/10686967.2017.11918508

P50.1.028-2001 (2000). Methodology of functional modeling. Moscow: Gosstandart of Russia.

Ponomarev S.V., Mironov S.V. (2007). Formation and assessment of indicators of effectiveness and efficiency of QMS processes. Standards and Quality, 8, 70-72.

Quality manual of Becker \& K LLP (2015)

Raver E.N. (2009). Basics of Conscious Product Quality Management. Standards and Quality, 2, 86-87.

Repin V.V., Eliferov V.G. (2013). Process approach to management. Modeling of business processes. Mann, Ivanov and Ferber. 544 p. https://www.twirpx.com/file/100807/ 


\section{ENTREPRENEURSHIP AND SUSTAINABILITY ISSUES}

ISSN 2345-0282 (online) http://jssidoi.org/jesi/

2019 Volume 7 Number 2 (December)

http://doi.org/10.9770/jesi.2019.7.2(16)

Rodionova Yu.A. (2013). Organization of assessment and monitoring of a quality management system of the enterprise. Abstract of the dissertation, St. Petersburg. 18 p.

Rogov I.A., Zabashta A.G., Kazyulin G.P. (2000). General technology of meat and meat products. M: Kolos, 367 p. http://www.zodchii.ws/books/info-769.html https://spblib.ru/catalog/-/books/3881672-obsaa-tehnologia-masa-i-masoproduktov

Rogov I.A., Zabashta A.G., Kazyulin G.P. (2009). Meat and meat products technology. Book 1. General Meat Technology. Textbook M: Kolos, 565 p. https://www.twirpx.com/file/1060339/

Shragenheim, E. (2014). Theory of constraints in action: A systematic approach to improving the efficiency of the company. Moscow: Alpina Pablisher, 286 p.

Sobolkova A.V. (2008). Quality Management System as a Mechanism for Increasing Competitiveness at the Enterprises. Quality Management, 3, 25-27.

ST RK 3.15.1-2009 State System of Technical Regulation of the Republic of Kazakhstan. Certification of quality management systems. Basic provisions.

ST RK 3.15.2-2009 Procedure for performance of works on certification of quality management systems.

ST RK ISO 10001-2009 Quality management. Satisfaction of the consumer. https://online.zakon.kz/Document/?doc id=31426233

ST RK ISO 19011-2013 (IDT, ISO 19011:2011) Guidelines for auditing management systems. https://www.belstu.by/Portals/0/userfiles/125/GOST-ISO-19011-2013.docx

ST RK ISO 9000:2016 Quality Management Systems - Fundamentals And Vocabulary. https://www.iso.org/standard/45481.html

ST RK ISO 9001-2016 Quality management systems - Requirements. https://www.iso.org/standard/45481.html

ST RK ISO 9004-2010 (IDT, ISO 9004-2009) Managing for the sustained success of an organization. A quality management approach. https://online.zakon.kz/document/?doc_id=31306691\#pos=0;0

Standard of enterprise 4.2.3.-05, (2005). Technological requirements. M.: Standards, 24 p.

Standard of enterprise 7.2-02-2008, (2008). Manual on Management of Complaints from External Consumers. Monitoring and analysis of satisfaction. Moscow: Standards, 28 p.

Tsaprilov D.A., Chudaev A.V. (2007). Construction of the process control system as an element of the quality management system. Standards and Quality. 6, 106-109.

\section{Acknowledgements}

This research was supported by the project, which has received funding from the Ministry of Education and Science of the Republic of Kazakhstan, the Grant of a Scientific Project on the theme "Monitoring and optimization of food safety based on innovative nanotechnologies" (2015-2017, state registration number is 0115RK01777) 


\section{ENTREPRENEURSHIP AND SUSTAINABILITY ISSUES}

ISSN 2345-0282 (online) http://jssidoi.org/jesi/

2019 Volume 7 Number 2 (December)

http://doi.org/10.9770/jesi.2019.7.2(16)

Saule Ospandiyarovna, AKHMETOVA is the Associate Professor in Chemical Engineering of Almaty Technological University, Almaty, Kazakhstan. PhD in Technology of Inorganic Substances. Chartered Engineer-Chemist-Technologist (CEng), Researcher and Academic Staff of Higher Education Institutions with almost 35 year experience, a track record of over 100 publications, including monograph "Processing of low-grade phosphorites", 11 textbooks and teaching manuals, 8 USSR and RK patents, scientific papers and presentations on the conferences, acquisition of 5 projects. A Scholar of the International "Bolashak" Programme of the President of the Republic of Kazakhstan 2013-2014, Owner of the grant of the Ministry of Education and Science of the Republic of Kazakhstan "The Best Teacher of Higher Education Institutions - 2018”. Research areas: Complex processing of low-quality phosphatic raw materials into important products of economic value; Analysis and improvement of QMS of the enterprises for food industry of RK; Food Security; Ecology.

ORCID ID: orcid.org/0000-0001-7287-766X

Mariya Shayakhmetovna, SULEIMENOVA is the Associate Professor in Chemistry and Head of the department "Chemistry, Chemical Engineering and Ecology" of Almaty Technological University, Almaty, Kazakhstan. PhD in Chemical Kinetics and Catalysis. Her scientific and pedagogical experience is more than 30 years, a track record of 200 publications, including 20 textbooks, 1 monograpf, 10 USSR and RK patents, scientific papers and presentations on the conferences. Acquisition and advisor of 10 projects: 1 international and 9 Republican scientific projects finded by RK and IScTechC (the partner program of the USA). Area of scientific interests: catalytic synthesis of dyes and biologically active agents, creation of biomaterials for branches of agro-industrial complex, food security, ecology.

ORCID ID: orcid.org/0000-0001-5455-6475

Maksim Borisovich REBEZOV is the Professor of K.G. Razumovsky Moscow State University of technologies and management (the First Cossack University) and Professor in Ural State Agrarian University, Russia. Dr of Science (Agriculture). His scientific and pedagogical experience is more than 25 years, a track record of more than 400 publications, including 37 textbooks and teaching aids, 12 monographs, 36 patents of Russia and Kazakhstan, scientific papers and presentations at the conferences. Acquisition and support of 6 projects: 1 international and 5 republican scientific projects funded by the Republic of Kazakhstan and the Russian Federation. Area of scientific interests: food biotechnology, production of functional food, agrarian biotechnology, food safety, ecology.

ORCID ID: orcid.org/0000-0003-0857-5143

Register for an ORCID ID:

https://orcid.org/register

Copyright (C) 2019 by author(s) and VsI Entrepreneurship and Sustainability Center

This work is licensed under the Creative Commons Attribution International License (CC BY).

http://creativecommons.org/licenses/by/4.0/

(c) (7) Open Access 